\title{
Sukces w filozofi to dzieło przypadku. Wywiad z Josefem Mittererem
}

DOI: http://dx.doi.org/10.12775/LC.2016.047

Marzenna Cyzman: Książki Tamta strona filozofii i Ucieczka z dowolności, dotychczas wydane w języku niemieckim i polskim, są już szeroko znane i komentowane, o czym świadczą choćby dwa tematyczne numery „Constructivist Foundations” poświęcone Twojej filozofii. W obszarze języka polskiego i niemieckiego coraz więcej jest odniesień do nie-dualizującej filozofii. Czy zatem Josef Mitterer, patrząc w lustro, myśli sobie - osiągnąłem sukces, stworzyłem nową ciekawą i inspirującą koncepcję?

Josef Mitterer: Absolutnie nie! Myślę, że miałem po prostu bardzo dużo szczęścia. Mój, jak to nazwałaś, sukces, wiąże się z szeregiem przygodnych zdarzeń. Doprowadziły one w końcu do tego, że zdecydowano się opublikować i komentować moje prace. Równie dobrze mogłoby się to wcale nie zdarzyć. Znam wiele znakomitych moim zdaniem książek filozoficznych, które przechodziły bez echa, a nazwisk ich autorów nie wymienia się w żadnych czasopismach. Po prostu nie mieli tyle szczęścia, co ja.

Marzenna Cyzman: Co więc zadecydowało o tym, że Mitterer jest obecnie już tak znany i tak szeroko komentowany?

Josef Mitterer: Jak pisałem w przedmowie do Tamtej strony filozofii pierwotnie moja koncepcja, którą wyłożyłem w doktoracie, spotkała się z niezrozumieniem. Pytano mnie, czy przypadkiem nie stroję sobie żartów. Życzliwsi namawiali do wycofania się z bzdur, które głoszę. Zabroniono mi też w pewnym momencie wykładania filozofii, bo przecież głosiłem pożegnanie $z$ prawda, byłem więc relatywistą i potencjalnie mogłem zaszkodzić młodzieży. To wynikało z niesprzyjających okoliczności, filozofia kilkadziesiąt lat temu była inna, niż jest teraz. Akademia ignorowała, nadal w pewnych środowiskach ignoruje, konstruktywizm. Co mi pomogło? Może wywiad, jakiego udzieliłem dla „Spiegla”? To, że $\mathrm{w}$ pewnym momencie zaproponowano mi pracę w Klagenfurcie i znalazłem się w ramach instytucji? To, że pewne osoby uznały, że to, co mówię, nie jest jednak pozbawione sensu i postanowiły zainteresować wydawców moją koncepcją? Trudno powiedzieć. Stało się to w sposób przypadkowy i zakończyło właśnie tak, że ludzie chcą o nie-dualizującej filozofii dyskutować.

Marzenna Cyzman: Dużą rolę odegrał chyba tu też wielki uczony, fundator radykalnego konstruktywizmu, Ernst von Glasersfeld?

Josef Mitterer: Glasersfeld zadzwonił do mnie kiedyś, po przeczytaniu moich tez. Muszę przyznać, że nie od razu skorzystałem z jego propozycji dyskusji. To stało się później. 
Zaprzyjaźniliśmy się. Muszę przyznać, że jego wpływ na moje myślenie jest ogromny. Choć spieraliśmy się bardzo często, a Ernst nie mógł chyba do końca zrozumieć różnic między naszymi koncepcjami, ja cały czas upierałem się, że one są.

Marzenna Cyzman: Obecnie opiekujesz się Archiwum prac Glasersfelda w Innsbrucku.

Josef Mitterer: Tak, postanowiliśmy otworzyć to Archiwum, aby uhonorować ogromny dorobek Glasersfelda. To hołd, jaki składamy wielkiemu myślicielowi, a także okazja do propagowania konstruktywizmu.

Marzenna Cyzman: Skoro mowa o myślicielach, którzy inspirowali Mitterera, to niewątpliwie obok Glasersfelda trzeba by wymienić Ludwika Flecka, tu polski więc akcent, i Richarda Rorty'ego.

Josef Mitterer: Tak, z Rorty'm spotykałem się. Był niewątpliwie wybitnym myślicielem. Dałem mu do przeczytania moje tezy, wiem, że przeczytał bardzo starannie, nawet zrobił sporo komentarzy na marginesie. Nie dane mi było nigdy jednak tego egzemplarza zobaczyć. Rorty jest zresztą znakomitym przykładem tego, od czego zaczęliśmy naszą rozmowę. Sława filozoficzna jest kwestią przygodną, a uznanie danego filozofa wynika z różnych okoliczności i rozmaicie wygląda w zależności od czasu. Rorty’emu wcale dobrze się nie wiodło w Princeton. Miał przecież problemy z publikacją Filozofii a zwierciadła natury. A jest obecnie jednym z najbardziej znanych filozofów na świecie, choć nadal są tacy, teraz może mniej niż za jego życia, którzy odmawiają mu miana prawdziwego filozofa. Co to zresztą znaczy prawdziwy filozof? Dla wielu to ten, który zgłębia poważne problemy filozoficzne, jak prawda oczywiście. Zależy to jeszcze od ośrodka, w którym pracuje, od tego, jakie są przyjęte w nim przekonania.

Marzenna Cyzman: Te akurat problemy Mitterera nie interesują?

Josef Mitterer: Problemy uznawane za filozoficzne Mitterera bardzo interesują. Jak wiesz, przez wiele lat pracowałem w branży turystycznej. Obwoziłem amerykańskie wycieczki po Europie. Bywaliśmy także w Polsce, w Warszawie. Ja wtedy nie przestawałem być filozofem, co więcej - miałem w czasie tych wycieczek, podczas rozmów z ludźmi, doskonałą okazję do testowania własnej filozofii. Interesowało mnie to, jak ludzie konstruują realność i prawdę. Co uznają za prawdziwe? Czy w Wersalu jest teraz król? Czy to jest prawdziwe? Zadawałem tego typu pytania w czasie naszych wycieczek do różnych europejskich miast. Uzyskiwałem ciekawe odpowiedzi od często zaskoczonych ludzi. Zwykłych ludzi, turystów, nie profesorów filozofii. Interesuje mnie tego typu eksperymentowanie w filozofii. Interesuje mnie to, jak kreujemy paradoksy, o tym też zresztą napisałem pracę.

Marzenna Cyzman: Lepiej jednak zajmować się filozofią instytucjonalnie?

Josef Mitterer: Trudno powiedzieć, czy lepiej. Na pewno daje to więcej możliwości. Mogłem i nadal mogę, choć jestem już na emeryturze, wygłaszać odczyty na konferencjach i w czasie seminariów, które gromadziły tysiące ludzi, otrzymywać dziesiątki maili, poznawać wielu ludzi, którzy inspirowali moje myślenie. Bycie w instytucji to jednak kwestia kompromisów. Akademia to wiele kwestii formalnych, jak ścieżka kariery, jaką się wybiera, i jaką wielu bardzo umiejętnie modeluje. Znam sporo osób, które przed wyborem tematu pracy doktorskiej starannie rozpoznają, jaka filozofia jest obecnie modna, czy w danym ośrodku dominuje kantyzm, czy może heideggeryzm, bo to może im zrobienie kariery ułatwić. Nie potępiam tego oczywiście, tak już jest. Potwierdza to tylko moją tezę o przygodności sukcesu filozoficznego. O tym, że nie ma filozofii lepszej, gorszej, bardziej adekwatnej, 
można tu mnożyć przymiotniki. Filozofami określonego typu stajemy się ze względu na ośrodek, w którym się kształcimy, profesorów, których spotykamy, lektury, które dają nam do czytania, dominujące w danym czasie trendy. W dużej mierze to kwestia mody, która przechodzi, zastępowana inną.

Marzenna Cyzman: Ale Ty niechętnie mówisz o własnej filozofii?

Josef Mitterer: To nie tak, że niechętnie mówię. Mówię całkiem często, w Toruniu, na sympozjum konstruktywistycznym, też mówiłem o nie-dualizmie. Nie zakładam tylko, że jest jakaś jedyna słuszna wykładnia mojej filozofii. Kiedy jestem pytany o jej sens, to mówię, jak sama wiesz, że moja filozofia jest tym, co sam/sama z niej uczynisz, jak ją zinterpretujesz. Zauważ, że w „Constructivist Foundations” są też artykuły krytycznie odnoszące się do mojej filozofii. I to jest O. K., to są czyjeś interpretacje from now on nie-dualizmu. One mogą mi się z jakichś względów nie podobać, ale przecież mogą mi się nie podobać też te pozytywne.

Marzenna Cyzman: Czyli Glasersfeldowe myślenie w kategoriach opcji do wyboru?

Josef Mitterer: Tak. Tak też sam uczyłem epistemologii. Pokazywać różne sposoby konstruowania problemów. Tak też jest tu, w Kirchbergu. Dyskutujemy o Wittgensteinie, ale nie w jeden określony sposób. Są tu i mocni realiści, i konstruktywiści. Nie zgodzą się może nigdy co do swych interpretacji, ale mogą je na równych prawach prezentować i możemy o nich dyskutować.

Marzenna Cyzman: Zatem należałoby Ci życzyć jak najwięcej rozmaitych interpretacji from now on nie-dualizmu?

Josef Mitterer: Bardziej chyba więcej czasu, bym mógł pracować nad kolejnymi propozycjami, nad directions of thinking. Cały czas jestem zajęty, prowadzę seminaria, wyjeżdżam, współorganizowałem też to Sympozjum w Kirchbergu. Ciągle za mało czasu na pisanie.

Marzenna Cyzman: A my właśnie na trzecią Twoją książkę czekamy. Życzę więc Tobie i nam wszystkim, zwłaszcza wielbicielom Twoim i Twojej filozofii, a tych akurat w Toruniu masz sporo, aby ta książka właśnie jak najszybciej została napisana i opublikowana. I dziękuję bardzo za rozmowę.

Z Josefem Mittererm w Kirchbergu (Austria) rozmawiała w sierpniu 2015 roku Marzenna Cyzman*

\footnotetext{
* Josef Mitterer - emerytowany profesor Instytutu Filozofii Alpen-Adria-Universität w Klagenfurcie (Austria). Autor Tamtej strony filozofii. Przeciwko dualistycznej zasadzie poznania (przeł. M. Łukasiewicz, Oficyna Naukowa, Warszawa 1996) i Ucieczki z dowolności (przeł. A. Zeidler-Janiszewska, Oficyna Naukowa, Warszawa 2004). E-mail: Josef.Mitterer@aau.at.

Marzenna Cyzman - adiunkt w Zakładzie Teorii Literatury Instytutu Literatury Polskiej Uniwersytetu Mikołaja Kopernika. Bada problemy z pogranicza filozofii i literaturoznawstwa. Opublikowała ostatnio książkę Nieznośna płynność rzeczy. Dyskurs, interpretacja, retoryka w nie-dualizującym sposobie mówienia, Toruń 2015), która stanowi pierwszą monografię nie-dualizującego sposobu mówienia Josefa Mitterera. Email: marzennacyzman@poczta.onet.pl.
} 